\title{
MIKROHISTORIE NIEMIECKOJĘZYCZNYCH MIESZKAŃCÓW PROWINCJI POZNAŃSKIEJ A GEOPOLITYKA
}

\author{
ELŻBIETA NOWIKIEWICZ1 \\ (Uniwersytet Kazimierza Wielkiego w Bydgoszczy)
}

\begin{abstract}
Słowa kluczowe: Prowincja Poznańska, mikrohistorie, autobiografia, historia faktyczna, doświadczana i zapamiętana
\end{abstract}

Key words: Poznań Province, micro-stories, autobiography, actual, experienced and remembered history

\begin{abstract}
Abstrakt: Elżbieta Nowikiewicz, MIKROHISTORIE NIEMIECKOJĘZYCZNYCH MIESZKAŃCÓW PROWINCJI POZNAŃSKIEJ A GEOPOLITYKA. „PORÓWNANIA” 12, 2013, T. XII, s. 55-71. ISSN 1733-165X. Badanie historii terenów, które znalazły się w dawnych granicach Prowincji Poznańskiej (1815-1918) było w okresie rozbiorów narzędziem, przy którego pomocy określano, kreowano i manipulowano samodefiniowanie się tu niemieckojęzycznych przybyszów/migrantów. Szczególnie dużo troski poświęcano ze zrozumiałych względów związkom tych terenów z pruską i niemiecką przeszłością, co miało służyć legitymacji i propagowaniu niemieckiej obecności na tym terenie. W ten sposób budowana i upowszechniana lokalna tożsamość wyrażała się instrumentalnym operowaniem przeszłością Prowincji Poznańskiej. Warto w tym kontekście odpowiedzieć na pytanie, jaką rolę odegrała polityka w przedefiniowaniu historycznego obrazu Prowincji Poznańskiej oraz w jaki sposób te "forsowane na górze" reinterpretacje historii regionu oraz bieżące działania władzy są odbierane przez zwykłych obywateli. To jest trudne i pozostaje nadal w fazie badań. Jednak już w świetle narracji autobiograficznych można zwrócić uwagę na pewne prawidłowości. Mikrohistorie pomogą odpowiedzieć na pytanie, czy autorzy w swoich osobistych refleksjach identyfikują się z linią polityczną realizowaną przez rządzących, jak doświadczali działań państwa, jak je zapamiętali i jak o nich piszą, czyli jak współistnieją ze sobą: historia faktyczna, doświadczana i zapamiętana.
\end{abstract}

Abstract: Elżbieta Nowikiewicz, MICRO-STORIES OF GERMAN SPEAKING INHABITANTS OF THE POZNAŃ PROVINCE AND GEOPOLITICS. "PORÓWNANIA" 12, 2013, Vol. XII, p. 55-71. ISSN 1733-165X. The study of the history of the lands which were within the old bor-

\footnotetext{
${ }^{1}$ Correspondence Address: elzbietanowikiewicz@gmail.com
} 
ders of the Poznan Province (1815-1918) was, during the partitions, a tool which was used to define, create and manipulate self-defining of German speaking newcomers/migrants. A lot of attention was paid, for obvious reasons, to relations of these lands with the Prussian and German past, which was to legitimize and promote the German presence in this area. The local identity, built and spread in this way was expressed by an instrumental use of the past of the Poznan Province. It is worth answering a question about the role of politics in re-defining a historical view of the Poznan Province and the ways in which the 'imposed' reinterpretations of the region's history and current actions of the authority were perceived by ordinary citizens. It is difficult and still being researched. However, certain regularities can be noticed in the light of autobiographical narration. Micro-stories can help to answer the question whether the authors in their personal reflections identified themselves with the political line of the rulers, how they experienced and remembered the actions of the state, how they remembered and wrote about them, in other words, how actual, experienced and remembered histories coexist

Elżbieta Rybicka pisze za Edwardem Saidem, że nie ma niewinnego kulturowego i literackiego dyskursu o przestrzeni, bowiem „coraz częściej stawia on nas przed pytaniami o politykę miejsca, ideologiczne zawłaszczenia, przemoc symboliczną kulturowej mapy nawet prywatnego terytorium" i konkluduje, że "geopoetyki nie sposób oddzielić od geopolityki" 2 . Zauważa przesunięcie akcentu z poetyki przestrzeni na politykę miejsca, z ontologii na ideologię. Podkreśla, że w tym kontekście szczególne zainteresowanie budzą m.in. przestrzenie pogranicza i wielokulturowe hybrydy, co nie oznacza „wynajdywania świata na nowo, lecz nade wszystko większą wrażliwość na przestrzenne usytuowanie kultury, historii, podmiotu, bytów społecznych"3.

Wielkie Księstwo Poznańskie (Prowincja Poznańska) ${ }^{4}$ powstało po rozbiorach Polski w wyniku postanowień, które zapadły na kongresie wiedeńskim. Jego

${ }^{2}$ E. Rybicka, Geografia, literatura, wyobraźnia: w stronę wspólnego stownika. „Tematy z Szewskiej” 2011, nr 1 (5), s. 42.

3 Ibidem, s. 42.

${ }^{4}$ Wielkie Księstwo Poznańskie od momentu powstania stanowi integralną część państwa pruskiego, jednak w przeciwieństwie do sąsiednich Księstw Pomorza i Śląska zachowało wyższą rangę. Po 1848 roku nazwa ta w oficjalnym obiegu przestaje istnieć i zostaje zastąpiona przez urzędową Prowincję Poznańską. W okresie zaostrzenia polityki wobec Polaków pojawia się termin 'Ostmark' [Marchia Wschodnia], zaczerpnięty z terminologii okresu średniowiecza, co miało przypominać o historycznych walkach o panowanie na wschodnich rubieżach. Do 1935 roku termin 'Ostmark' używany jest właśnie kontekście walki [W. Gerke, Das Identitätsbewußtsein der Deutschen im Posener Land, w: Beiträge zur deutsch-polnischen Nachbarschaft. Red. C. J. Kenéz, H. Neubach, J. Rogall. BerlinBonn 1992, s. 28-29]. Świadczy o tym m.in. tendencyjna i upolityczniona literatura Marchii Wschodniej ['Ostmarkenliteratur'], związana miejscem akcji z Prowincją Poznańską i poruszająca problematykę regionalną. E. Połczyńska, "Im polnischen Wind”. Beiträge zum deutschen Zeitungswesen, Theaterleben und zur deutschen Literatur im Grossherzogtum Posen 1815-1918. Poznań 1988; M. Wojtczak, „Ostmarkenliteratur". Prowincja Poznańska w literaturze niemieckiej lat 1890-1918. Poznań 2001. 
utworzenie nie uwzględniało wszystkich uwarunkowań geograficznych i historycznych, a granice zaanektowanego przez Prusy terytorium nie pokrywały się w całości z historyczną Wielkopolską ${ }^{5}$, co upoważnia do rozważań w kierunku polityki miejsca. Prowincja Poznańska jest zatem administracyjnie i geopolitycznie definiowalną przestrzenią, celem polityki osadniczej najpierw rządu pruskiego, a po zjednoczeniu Niemiec w 1871 roku - niemieckiego, która, wbrew oczekiwaniom nie przyniosła żądanych efektów i nie zdołała wystarczająco i na trwałe wzmocnić tu żywiołu niemieckiego.

Niemiecką działalność osadniczą w Poznańskiem ${ }^{6}$ starano się wspierać na różne sposoby, między innymi działaniami ustawodawczymi (Kulturkampf, powstanie Komisji Kolonizacyjnej, rugi pruskie, ustawy oświatowe ${ }^{7}$ ). Z kolei zwerbowani do Prowincji Poznańskiej pruscy urzędnicy i nauczyciele mieli być nie tylko wykonawcami polityki władz $\mathrm{w}$ terenie ${ }^{8}$, ale $\mathrm{i}$ animatorami życia publicznego, a przynajmniej w założeniu powinni byli wspierać wysiłki władz w tym zakresie. Martin Broszat pisze w związku z tym o „zurzędniczeniu“ ludności niemieckiej, szczególnie w Poznaniu czy Bydgoszczy i ocenia, że „taki sztucznie wprowadzony do tej prowincji żywioł niemiecki w niewielkim stopniu nadawał się do tego, aby trwale oprzeć na nim panowanie prusko-niemieckie" ${ }^{\prime \prime}$. Niemniej niektórzy spośród urzędników służby publicznej, nauczycieli i wykładowców widzieli się w roli tzw. krzewicieli niemczyzny [Träger des Deutschtums]. Ich starania uzupełniali działacze lokalnych stowarzyszen, redaktorzy czasopism regionalnych i autorzy literatury ojczyźnianej [Heimatliteratur], prezentujący fikcję wspaniałego życia na niemieckich Kresach Wschodnich, co również miało pomóc w osiągnięciu żądanego efektu $\mathrm{w}$ postaci odwrócenia niekorzystnych dla strony niemieckiej tendencji w statystykach narodowościowych. Z takiego samego powodu uprawiano zakrojoną na szeroką skalę politykę kulturalną. Program kulturalnej odbudowy tej wschodniej prowincji przewidywał działania wspierające odnowę starych i budowę nowych instytucji. Adresatem była ludność niemiecka, którą należało silniej związać $\mathrm{z}$ tym, $\mathrm{w}$ powszechnym odczuciu, mało atrakcyjnym regionem. Żywiono $\mathrm{w}$ ten sposób nadzieję na zażegnanie poczucia obcości, w którym upatrywano

5 T. Serrier, Provinz Posen, Ostmark, Wielkopolska. Eine Grenzregion zwischen Deutschen und Polen 1848-1914. Marburg 2005, s. 262.

${ }^{6}$ Historia osadnictwa niemieckiego w Wielkopolsce sięga przynajmniej XIII wieku. Nie osiągnęła tu jednak nigdy takich rozmiarów i znaczenia, jak w sąsiednich regionach. Okres rozbiorów stanowi kolejny rozdział w historii tego zjawiska.

7 Ponieważ pruska i niemiecka polityka wobec Polaków w okresie zaborów jest bardzo dobrze zbadanym zagadnieniem, ograniczę się jedynie do odnotowania tego faktu.

${ }^{8}$ Urzędnikom przyznano dodatki kresowe oraz inne subwencje i środki finansowe, a służbę na kresach liczono tak, jakby spędzony tu czas był czasem wojny. M. Broszat, 200 lat niemieckiej polityki wobec Polski. Warszawa 1999, s. 172.

${ }^{9}$ Ibidem, s. 197. 
jedną z przyczyn sytuacji demograficznej i spadku liczby ludności niemieckiej, zarówno z tytułu niższego niż wśród Polaków przyrostu naturalnego, jak i ujemnego salda migracji na przełomie XIX i XX wieku' ${ }^{10}$.

Niełatwo jest $\mathrm{w}$ dużym skrócie przedstawić zawiłe determinanty polityczne i działania władz, zorientowane na przyciągnięcie oraz zatrzymanie tu niemieckich migrantów, a w dalszym zamierzeniu, służące integracji ludności miejscowej z niemieckimi mieszkańcami oraz jej asymilacji z kulturą osadnictwa niemieckiego, nawet jeśli dotyczą tak niewielkiego regionu, jakim jest Prowincja Poznańska. Proces żmudnego budowania i umacniania identyfikacji niemieckich mieszkańców z regionem miała też wspierać właściwa narracja historyczna, „instrumentalizująca pamięć $\mathrm{w}$ celu obrony takiej interpretacji przeszłych wydarzeń, która [...] podważa inne interpretacje"11. Dlatego wszelkie posunięcia, zmierzające do zagospodarowania tej części Marchii Wschodniej i uargumentowania pruskiej i niemieckiej obecności na tym terenie, dokumentowano, utrwalano i reorganizowano w najrozmaitszy sposób, zgodnie z wyznacznikami polityki historycznej władz. Obchodzono rocznice, stawiano pomniki, ustalano dni pamięci i nadawano im odpowiednie znaczenie ${ }^{12}$. Dodatkowo publikowano teksty popularno-naukowe oraz rozpowszechniano tzw. 'Ostmarkenliteratur'13. W ten sposób za sprawą różnych mediów odpowiednie treści stawały się sprawą publiczną i elementem pamięci zbiorowej. Jednym z filarów omawianej 'Öffentlichkeitsarbeit' [kształtowanie opinii publicznej] władz pruskich i niemieckich $w$ Poznańskiem $w$ ramach realizacji idei osadnictwa niemieckiego na tych ziemiach jest popularyzacja mitu o „niemieckim Wschodzie”14, na którym państwo buduje tu swoją dominację i usiłuje od nowa umiejscowić pamięć kolektywną15, a metodą okazuje się przeniesienie punktu ciężkości z historii wydarzeń na ich percepcję i interpretację.

10 Ibidem, s. 191-192.

11 S. Kapralski, Pamięć, przestrzeń, tożsamość. Próba refleksji teoretycznej, w: Pamięć, przestrzeń, tożsamość. Red. S. Kapralski. Warszawa 2010, s. 20.

12 Skłonność utrwalania pamięci poprzez obchodzenie rocznic, świąt i stawianie pomników oraz wspominanie osób i wydarzeń jest charakterystyczna dla większości krajów i nie jest ani pruską, ani niemiecką specyfiką. Należy jednak podkreślić, że zasadniczo nie chodzi przy tym o uznanie wielkości i zasług danej osoby: pisarza, naukowca, władcy, ale o znaczenie tej osoby lub wydarzenia dla teraźniejszości lub o rodzaj łącznika między wtedy a dziś.

13 Bohaterami powieści z cyklu tzw. literatury Marchii Wschodniej są osadnicy niemieccy jako tzw. kulturträgerzy i pionierzy niemczyzny. Zadaniem tej literatury jest m.in. powielanie argumentów przemawiających za niemiecką obecnością w Poznańskiem.

${ }^{14}$ H. H. Hahn, E. Hahn, Der 'deutsche Osten' - Mythos? Realität? Verlorenes Traumland? w: Narrative des Nationalen. Deutsche und polnische Nationsdiskurse im 19. und 20. Jahrhundert. Red. I. Surynt, M. Zybura. Osnabrück 2010, s. 386.

15 Popularyzację mitu można traktować jako doskonały przykład zjawiska legitymizowania rzeczy nowych przez ,wynalezienie' ich tradycji w myśl zasady, że jeśli daje się wykazać, że jakiś fakt czy proces ma korzenie w przeszłości tym lepiej. S. Kapralski, op. cit., s. 22. 
Warto $\mathrm{w}$ związku z tym skierować uwagę na mikrohistorie, studium przypad$\mathrm{ku}^{16} \mathrm{i}$ w oparciu o dostępne (według mojej wiedzy z tej perspektywy dotąd niebadane) autobiografie niemieckojęzycznych pisarzy (Niemców i Żydów), którzy w okresie 1815-1918 przez jakiś czas mieszkali w Prowincji Poznańskiej, odpowiedzieć na pytanie, jak zasygnalizowane na wstępie działania rządzących były odbierane przez nich jako migrantów oraz czy w swoich osobistych refleksjach identyfikują się z linią polityczną realizowaną tu najpierw przez władze pruskie, a później niemieckie.

Zatem obok historii zdarzeniowej pojawia się kwestia, jak „sprawy się faktycznie miały"17 i jak wskazani autorzy, jako napływowi mieszkańcy Prowincji, oceniali rozgrywającą się na ich oczach politykę, jak doświadczali działań państwa, jak je zapamiętali i jak o nich piszą ${ }^{18}$. Przez takie porównanie realizuje się jednoczesne wspólistnienie historii faktycznej, doświadczanej i zapamiętanej, które podkreśla różnicę między subiektywną przestrzenią autorów, przestrzenią obiektywną ich realnego życia i naukową, definiowaną przez badaczy danej dziedziny ${ }^{19}$.

Julie Burow (1806-1857), Ludwig Kalisch (1814-1882), Otto Roquette (18241896), Adelheid Sturm (1840-1911), Clara Viebig (1860-1952), Albert Steuer (18741967), Ernst Toller (1893-1939), Alfred Cohn (1901-1961), Kurt Ihlenfeld (1901-1972) i A. E. Johann (właściwe nazwisko Alfred Ernst Johann Wollschläger, 1901-1996) jako autorzy związani z Poznańskiem ${ }^{20}$ są reprezentantami indywidualnej i kolektywnej pamięci pewnej czasowo, przestrzennie i w dużym stopniu socjalnie homogenicznej grupy. Dlatego w oparciu o ich autobiograficzny materiał ${ }^{21}$ omówio-

${ }^{16} \mathrm{O}$ znaczeniu badań nad mikrohistorią i badań doświadczeń: H. J. Karp, R. Traba, Czy codzienność można pamiętać? Wspomnienia z Warmii i Mazur jako fragment pamięci kulturowej Niemców, Polaków i Ukraińców, w: Codzienność zapamiętana. Warmia i Mazury we wspomnieniach. Red. H. J. Karp, R. Traba. Olsztyn-Warszawa 2004, s. 7-22.

17 Ibidem, s. 8.

18 A. Assmann, Der lange Schatten der Vergangenheit. Erinnerungskultur und Geschichtspolitik. München 2006, s. 16.

19 A. Ungern-Sternberg v., „Erzählregionen“. Überlegungen zu literarischen Räumen mit Blick auf die deutsche Literatur des Baltikums, das Baltikum und die deutsche Literatur. Bielefeld 2003, s. 879.

${ }^{20}$ Twórczość fikcjonalna wymienionych pisarzy nie musi dotyczyć lokalnych kwestii ani wynikać z lokalnej specyfiki. Mimo, że nasycenie wątkami poznańskimi jest w poszczególnych autobiografiach różne, a miejsce akcji oprócz Prowincji Poznańskiej tworzy jeszcze szereg innych miejscowości, zidentyfikowane autobiografie będą rozpatrywane wyłącznie w poznańskim kontekście.

21 J. Burow, Versuch einer Selbstbiographie. Bromberg 1857; L. Kalisch, Bilder aus meiner Knabenzeit. Leipzig 1872; O. Roquette, Siebzig Jahre. Geschichte meines Lebens. Darmstadt1896; E. Toller, Eine Jugend in Deutschland. Amsterdam 1933; K. Ihlenfeld, Das dunkle Licht. Blätter einer Kindheit. Hamburg 1956; A. E. Johann, Dies wilde Jahrhundert. München 1989 oraz prace zredagowane, wydane po śmierci autorów: Viebig Clara. Mein Leben: autobiographische Skizzen. Red. Ch. Aretz. Hontheim 2002; Sturm Adelheid geb. Deinhardt, Lebens-Erinnerungen einer Professorenfrau. Berlin 1911; Steuer Albert, Erinnerungen des 
na zostanie wyłącznie kwestia subiektywnego odbioru zamieszkiwanej przez nich geopolitycznej przestrzeni. Ponieważ stanowią względnie jednorodną grupę zawodową (są w większości dziećmi urzędników i nauczycieli, jest jeden pastor i jeden ksiądz, oprócz tego mamy dwóch potomków żydowskich kupców), to nie jest ona reprezentatywna dla wszystkich Niemców mieszkających tutaj w latach 1815-1918, wobec czego przedstawiają jedną z wielu "prawd” o przeszłości22. Jednak ze względu na znaczny stopień „zurzędniczenia” niemieckiego społeczeństwa w dużych miastach, zidentyfikowane w wyniku poszukiwań badawczych teksty autobiograficzne zasługują na tym większą uwagę, ponieważ pomagają rozważyć, jak dalece indywidualna pamięć autobiografów jako przedstawicieli tej konkretnej grupy ${ }^{23}$, uzupełnia pamięć polityczną i narodową ${ }^{24}$ o Prowincji Poznańskiej jako "prastarym niemieckim kraju” oraz czy lub w jakim stopniu autobiografowie dystansują się wobec oficjalnego stanowiska tamtej polityki historycznej, propagującej mit "niemieckiego Wschodu”.

Percepcja obu mitów zbadana na podstawie literatury podmiotu pokazuje, że indywidualne postrzeganie geopolitycznej przestrzeni nie musi być identyczne z ideologicznym jej zawłaszczeniem, wynikającym z aktualnych interesów politycznych ówcześnie rządzących. Widać bowiem wyraźnie, że im wcześniej urodzili się autobiografowie - lata ich życia przypadają na początek istnienia jednostki administracyjnej, jakim było Wielkie Księstwo Poznańskie - tym krytyczniej postrzegają spędzony tu czas. Z perspektywy urodzonych jeszcze przed 1840/50 rokiem Wielkie Księstwo Poznańskie traktowane jest zazwyczaj jak odległe Kresy, peryferie Prus, co, jak wiadomo nie przystaje do kreowanej przez władze i przesyconej propagandą ideologiczną obiecującej wizji pracy w Marchii Wschodniej, w pewnym sensie „ziemi obiecanej”. Otto Roquette (1824-1896), który spędził tu okres od 1824 do 1839 roku, wspomina:

Powszechne było narzekanie na tę beznadziejną okolicę (okolice Gniezna - E.N.), na nieprzyjemne spacery w głębokim piachu, bez cienia, bo wokół nie było widać ani jed-

Posener Domherren. Red. M. Krzoska. München 2010; Cohn Alfred, Erinnerungen an Bromberg. Red. E. Alabrudzińska, B. Janiszewska-Mincer, Toruń 2003.

22 H. J. Karp, R. Traba, op. cit., s. 20.

${ }^{23}$ Ze względu na wykonywany przez rodzica zawód urzędnika lub nauczyciela, autorzy są dziećmi reprezentantów władzy w terenie (np. O. Roquette, A. Sturm, A. E. Johann).

${ }^{24}$ Według A. Assmann wszędzie tam, gdzie historia służy budowaniu tożsamości, gdzie jest przejmowana przez obywateli, a przez polityków instrumentalizowana, można mówić o pamięci politycznej lub narodowej. W odróżnieniu od wielogłosu oddolnej pamięci społecznej, obejmującej pamięć komunikatywną i kulturową, która przemija wraz z odchodzeniem kolejnych pokoleń, pamięć polityczna/narodowa jest bardziej jednorodną konstrukcją, silnie osadzoną w instytucjach politycznych, nastawioną na przetrwanie i odgórnie oddziałującą na społeczeństwo [A. Assmann, op. cit., s. 37], a w zamierzeniu ma służyć powstaniu tożsamości lokalnej, „montowanej” na doraźne potrzeby ideologów. 
nego drzewa, na brak wszelkiego uroku, na którym mógłby spocząć wzrok. [...]. Co do tego, że pobyt tu był czymś strasznym, ponieważ prawie wszyscy widzieli już kawałek wielkiego świata, panowała jednomyślność. Dlatego żartowano z osobliwych przyjemności, które próbowano tu sobie sprawić. I jeśli w dzieciństwie nigdy nie widziałem krajobrazu, który trwale wywarłby na mnie wrażenie, to dzięki rozmowom i uwagom dorosłych przyjąłem pogląd, że ten bezkresny piach, te marne sosny, ta zazwyczaj źle uprawiana piaszczysta gleba, są czymś niezadowalającym i brzydkim. Moja wrażliwość na piękno, jak i tęsknota za bardziej intrygującą dalą, zostały w związku z tym wcześnie obudzone ${ }^{25}$.

Kolejną zaobserwowaną prawidłowością jest stosunkowo rzadkie i lakoniczne przywoływanie we wspomnieniach poznańskiego rozdziału w życiu, co może oznaczać, że autorzy w osobistych refleksjach niechętnie podporządkowują się szerszemu kontekstowi zdarzeń historycznych. Bo jeśli go niemal pomijają, to można przyjąć, że bardziej zajmują ich inne sprawy, subiektywnie ważniejsze, jak np. kwestie związane z prywatną przestrzenią wewnętrzną, a nie politycznogeograficzną. Przestrzeń ekspansji terytorialnej tworzy często tylko warstwę zewnętrzną i nie stanowi dla badanych autorów silnej duchowej głębi, dlatego większość traktuje ją marginalnie ${ }^{26}$. Są też tacy, jak Ernst Toller, z którego wypowiedzi wynika, że Niemcy „uważali się” (przez co daje do zrozumienia, że niekoniecznie nimi byli) „za rdzennych mieszkańców i prawdziwych panów tego kraju” 27. $\mathrm{Z}$ kolei Adelheid Sturm twierdzi, że tak naprawdę „nie było to terytorium niemieckie" 28 .

Milczenie lub pisanie bardzo mało na temat politycznego wymiaru pracy i życia w Poznańskiem może też oznaczać ignorowanie polityki kolonizacyjnej rządu pruskiego/niemieckiego i wszystkiego, co jest z nią bezpośrednio lub pośrednio związane. Nie da się również wykluczyć, że autobiografowie posuwają się do

25 „Allgemein war die Klage über die trostlose Oede der Gegend [um Gnesen - E.N.], über das schlechte Spazierengehen im tiefen Sande, die Schattenlosigkeit, da kein Baum ringsum zu sehen war, der Mangel an jeglichem Reiz, auf dem das Auge hätte ausruhen können. [...] Man war einig, daß dies eigentlich ein schrecklicher Aufenthalt sei, denn fast Alle hatten die Welt in größeren Kreisen gesehn, man belustigte sich über die sonderbaren Freuden, die man sich zu bereiten suchte. Und wenn ich so in meiner Kindheit niemals etwas von landschaftlicher Natur gesehn, was einen bleibenden Eindruck hätte machen können, so empfing ich durch Gespräche und Bemerkungen der Erwachsenen früh die Anschauung, daß dieser endlose Sand, diese dürftigen Kiefern, diese meist schlecht bebaute Sandfläche, etwas Unerquickliches und Häßliches sei. Dabei war meine Phantasie für Schöneres längst angeregt, und die Sehnsucht in eine glänzendere Ferne früh erwacht“. O. Roquette, Siebzig Jahre. Geschichte meines Lebens. Darmstadt 1894, s. 43-44.

${ }^{26}$ Dopuścić też należy sytuację odwrotną, że być może są wśród nich autorzy, którzy traktują polityczne zawłaszczenie tego regionu, jako coś niebudzącego wątpliwości, stąd praktycznie w ogóle nie odnoszą się do tej kwestii.

${ }^{27}$ E. Toller, Eine Jugend in Deutschland. Amsterdam 1933, s. 2.

28 A. Sturm, Erinnerungen einer Professorenfrau. Berlin 1911, s. 4. 
swoistej autocenzury ze względów patriotycznych, gdyż najpewniej nie należało pisać krytycznie o pruskiej/niemieckiej obecności w dawnej Wielkopolsce. Łatwiej było przecież przemilczeć to i owo lub ograniczyć się do ogólnych schematów i nie narażać się ${ }^{29}$. Wiadomo przecież, że pisanie wspomnień jest ukierunkowane na odbiorcę, stąd autorzy selekcjonują informacje i wybierają rozwiązanie, żeby narracja była przez niego akceptowana. Inaczej wyglądają przecież relacje zakładające upublicznienie treści, a inaczej te pisane 'do szuflady'.

W większości przypadków (wyj. A. E. Johann, Clara Viebig, Ernst Toller) pisarze nie toczą politycznej dyskusji, a polityka jest przez nich marginalizowana. $\mathrm{Z}$ tego powodu pytanie, czy wolno zakładać istnienie dużego rozdźwięku między oficjalnym nurtem pamięci a indywidualną perspektywą, pozostanie bez precyzyjnej odpowiedzi. Że istniał, jest bezdyskusyjne, o czym świadczy m.in. postawa C. Viebig (1860-1952). Choć pisarka sprawia wrażenie, jakby unikała zajmowania stanowiska wbrew oficjalnej narracji, to nie milczy, lecz chowa się za własną literaturą fikcjonalną ${ }^{30}$. Jej odautorskie komentarze na temat wydanej w 1904 roku powieści Das schlafende Heer są pretekstem do rozważań o polsko-niemieckim sąsiedztwie w Poznańskiem z polityką w tle. Mimo że ‘Ostmarkenliteratur' zaliczana jest do ważnego medium popularyzującego stanowisko władz niemieckich w przedefiniowaniu historycznego obrazu regionu, to powieść C. Viebig, mimo klasyfikacji jako 'Ostmarkenliteratur', poddaje krytyce podejmowane działania władz, wskazując na ich niską skuteczność, a nawet odwrotne efekty do zamierzonych. To ważna informacja, obnażająca słabości jednowymiarowej polityki Cesarskich Niemiec wobec Polaków. Pamięć biograficzna mówi w tym wypadku o tym, o czym społeczna nie jest jeszcze gotowa mówić.

Podczas mojego pobytu tam, sprawa polska wzbudzała sensację w polityce niemieckiej. Nie myślałam przecież jeszcze wtedy o pisaniu, nie byłam też świadoma, iż chłonęłam tamtą atmosferę, której oddech jest wyczuwalny w mojej powieści (Das schlafende Heer - E.N.), atmosferę pełną politycznych, ekonomicznych i religijnych konfliktów. Przez lata wierzono, że różnice zostały przezwyciężone. Jednak podczas wojny wybuchły na nowo z siłą uwolnionych żywiołów, konflikty, które próbowano zażegnywać rzucając obietnice lub idąc na ustępstwa - niestety - za późno. Konflikty te doprowadziły do bolesnej straty nie tylko Prowincji Poznańskiej, lecz również sporej części Górnego Śląska ${ }^{31}$.

29 J. Tazbir, O czym się pisać nie godziło. „Gazeta Wyborcza” z 27-28 grudnia 2003, s. 16-17.

${ }^{30} \mathrm{C}$. Viebig stosuje intertekstualny zabieg, nazywany w badaniach pamięci kulturowej „pamięcią literatury", czyli wspominaniem literatury w literaturze. R. Lachmann, Gedëchtnis und Literatur. Intertextualität in der russischen Moderne. Frankfurt/M. 1990 oraz B. Neumann, Literatur, Erinnerung, Identität, w: Gedächtniskonzepte der Literaturwissenschaft. Theoretische Grundlegung und Anwendungsperspektiven. Red. A. Erll, A. Nünning, H. Birk, B. Neumann. Berlin-New York 2005, s. 149-178.

31 „Während ich dort war, erregte die polnische Frage großes Aufsehen in der deutschen Politik. Ohne dass es mir bewusst war, denn ich dachte noch nicht daran zu schreiben, saugte ich mich voll 
Pisarka wskazuje w ten sposób na istotne błędy, których dopuszczono się w Poznańskiem.

Bez opowiadania się po którejkolwiek stronie wyraźnie pokazałam, jak wzniecano niepokoje, jak utrudniano łagodzenie niezadowolenia Polaków, jakie banalne błędy, wbrew politycznym zasadom i człowieczeństwu, popełnili Niemcy ${ }^{32}$.

Konsekwencją uprawianej polityki konfrontacji i budowania barykad jest w opinii autorki bezkompromisowe dążenie Polaków do odzyskania niepodległości.

A kiedy opowiadała o tamtym dniu, w którym jako młoda kobieta stała przy oknie i przyglądała się, jak na dole ze wsi Buk do Poznania na taczkach i wozach drabiniastych przewożono nieszczęsnych żołnierzy $\mathrm{z}$ odciętymi od noży fanatycznych polskich kobiet nosami i uszami, połamanymi rękami i nogami, w połowie wykrwawionych. Wtedy w siłę wyrosła przede mną polska rewolucja. Słyszałam klepanie kos, widziałam jak ich szeroki, świecący blask nabiera krwawych barw podczas żniwa kostuchy, widziałam w locie białego sokoła na czerwonym symbolu i słyszałam szalony wrzask tłumu:

'Jeszcze Polska nie zginęła -

Niech żyje Polska!'”33.

W dalszych rozważaniach nie sposób pominąć kolejnego ważnego czynnika wpływającego na treść i kształt wspomnień. Krystalizują się zawsze z uwzględnieniem perspektywy teraźniejszości. Wspomina się to, co aktualnie ma sens i uzasadnienie ${ }^{34}$, ponieważ współczesność determinuje indywidualne i społeczne

mit dieser Atmosphäre, deren Atem sich durch meinen Roman [Das schlafende Heer - E. N.] hindurchspüren läßt, eine Atmosphäre voller politischer, wirtschaftlicher und religiöser Konflikte. Jahrelang glaubte man, dass diese Meinungsverschiedenheiten beseitigt seien. Aber während des Krieges brachen sie los mit der Heftigkeit entfesselter Elemente, diese Konflikte, die man zu beseitigen versuchte, durch Versprechungen oder gemachte Konzessionen - leider - zu spät, diese Konflikte, die zu dem schmerzlichen Verlust nicht nur der Provinz Posen geführt haben, sondern auch eines guten Teils von Oberschlesien“. Viebig Clara. Mein Leben: autobiographische Skizzen. Red. Ch. Aretz. Hontheim 2002, s. 92.

32 „Ohne Partei zu ergreifen, habe ich am hellen Tag gezeigt, wie man schürte, wie man es verhinderte, die Unzufriedenheit der Polen zu löschen, welche Fehler, zu leicht zu verstehen, die Deutschen gegen die politischen Prinzipien und die Menschlichkeit begingen“. Ch. Aretz, op. cit., s. 92.

33 "Und wenn sie dann von jenem Tage sprach, an dem sie, als junge Frau am Fenster stehend, zusah, wie drunten auf Karren und Leiterwagen die unglücklichen Soldaten vom Dorfe Buk her in die Stadt Posen gebracht wurden, mit abgeschnittenen Nasen und Ohren, verstümmelten Armen und Beinen, halb verblutet unter den Messern fanatischer Weiber, dann wuchs die polnische Revolution gewaltig vor mir auf. Ich hörte das Dengeln der Sensen, ich sah deren breites, blitzendes Blank sich blutig färben unterm Mähen der Sensenmänner, ich sah den weißen Falken fliegen auf rotem Panier und hörte das wahnwitzige Gebrüll der Menge:

,Noch ist Polen nicht verloren -

Niech żyje Polska!'“ Ch. Aretz, op. cit., s. 48.

${ }^{34} \mathrm{~A}$. Degen, Was ist ein Erinnerungsort? Zu Begriff und Theorie topographischen Erinnerns in politischer und phänomenologischer Hinsicht. W: Erzählregionen. Regionales Erzählen und Erzählen über eine 
wspominanie, które nie wypływa z przeszłości lecz z teraźniejszości35. Już same porównanie dat wydań poszczególnych autobiografii ${ }^{36}$ pozwala zaobserwować, że wspominanie jest adekwatne do potrzeb wynikających $z$ aktualnej sytuacji. Konkretny moment, w którym się wspomina, wpływa przecież na tematyczne i emocjonalne punkty ciężkości. Zatem przeanalizowanie autobiograficznych treści $\mathrm{z}$ uwzględnieniem czasu ich spisania i udzielenie odpowiedzi na pytanie, $\mathrm{w}$ jakim momencie dziejowym i momencie życia autorów powstają, jest jak najbardziej zasadne, może nawet niezbędne, by lepiej rozeznać się w możliwych przyczynach selekcji poruszanych wątków i sposobie prowadzenia autobiograficznej narracji37.

Biorąc pod uwagę kolejny wyznacznik, tj. czas upływający między opisanymi wydarzeniami a momentem wspominania, można zauważyć, że w dwóch przypadkach mija nawet sześćdziesiąt lat, co nie pozostaje bez wpływu na „przypominanie sobie przeszłości" i różnice wynikające z kontekstu sytuacyjnego autobiografii oraz kontekstu sytuacyjnego przebiegu życia autobiografa ${ }^{38}$. Zatem i dystans czasowy, powstający między doświadczeniem a narracją o nim, determinuje pamięć. Najwyraźniej widać ten wpływ u A. E. Johanna, który snuje obszerne rozważania o nieuchronności przemian politycznych w Europie i w świecie, i uważa tęsknotę Polaków za własnym niepodległym państwem za uzasadnioną. Bardzo dobrze rozumie też konieczność politycznych zmian.

Na niemieckim Wschodzie (...) w pruskiej Prowincji Poznańskiej, wcześniejszej Wielkopolsce oraz na Górnym Śląsku budzą się Polacy, których zrozumiała tęsknota za własnym państwem między Niemcami a Rosją nie wygasła przez okrągłe 125 lat bezpaństwowości ${ }^{39}$.

A.E. Johann i C. Viebig, przywołując sformułowanie „der deutsche Osten”, nawiązują do mitu „niemieckiego Wschodu”. Warto zadać w tym miejscu pytanie,

Region. Ein polnisch-deutsch-norwegisches Symposium. Red. B. Neumann, A. Talarczyk. Aachen 2011, s. 80.

35 Por. G. Baumgartner, Zeit des historischen Gedächtnisses. www.erinnern.at/.../384_Baumgartner_ ... s. 11 (data dostępu: 01.03.2012). Marian Golka pisze o „tendencyjności” i „uzgadnianiu' przeszłości z teraźniejszością". M. Golka, Społeczna niepamięć. Pomiędzy zapominaniem a zamazywaniem, w: Pamięć, przestrzeń, tożsamość. Red. S. Kapralski. Warszawa 2010, s. 52.

${ }^{36}$ Lata życia autobiografów obejmują okres od 1806 (rok urodzenia Julii Burow) do 1996 (rok śmierci A. E. Johanna). Pierwsza autobiografia ukazała się w 1857 (J. Burow), ostatnia w 1989 roku (A. E. Johann). Cztery tytuły wyszły drukiem po śmierci autorów (A. Sturm, C. Viebig, A. Cohn, A. Steuer).

${ }^{37} \mathrm{O}$ czynnikach i mechanizmach jednostkowego zapominania:. M. Golka, op. cit., s. 51-52.

${ }^{38}$ H. J. Karp, R. Traba, op. cit., s. 20.

39 „Im deutschen Osten [...] regten sich in der preußischen Provinz Posen, dem früheren Großpolen, und in Oberschlesien die Polen, deren sehr verständliche Sehnsucht nach einem eigenen Staat zwischen Deutschland und Rußland an den rund 125 Jahren ihrer Staatenlosigkeit nie erloschen war". A. E. Johann, Dies wilde Jahrhundert. München 1989, s. 190. 
czy jest to wystarczający dowód na podporządkowanie się ideologii rządzących i ich reinterpretacji historii? Do pewnego stopnia być może tak, kiedy po latach, w konsekwencji utraty tej części Marchii Wschodniej, C. Viebig przedstawia byłą już Prowincję Poznańską jako rolnicze zaplecze Niemiec. W opublikowanym 17 lipca 1930 roku w Wiesbadener Tageblatt biograficznym tekście ${ }^{40}$, autorka wspomina „niemiecki Wschód” niczym utracony raj.

Dzięki Bogu, że moja mama nie doczekała, kiedy to miasto stało się polskie, za którego niemieckość mój kochający pokój ojciec z lufą przy policzku stał na schodach na warcie! Że miejsce, z którym kojarzyła pierwszą miłość, gdzie jej ojciec głosił kazania po niemiecku, że tamte bezkresne łany pszenicy - pełne spichlerze Prus - przypadły Polakom. Dzięki Bogu, że zasnęła przed największą z wojen ${ }^{41}$.

W tym samym okresie pisze jednak nadal o monotonnym, po prostu biednym kraju, w którym, tak jak u Adelheid Sturm, rosą same sosny. Nie unika przy tym kontrastowych porównań z Nadrenią, na tle której Prowincja Poznańska wypada niekorzystnie.

Mnie urodzonej na Zachodzie, w najpiękniejszym zakątku Nadrenii, nad łagodną Mozelą ze zboczami winorośli, na które z ciemnoniebieskiego nieba $\mathrm{z}$ uśmiechem spogląda wesołe słońce, ta bezkresna dal, bez gór, bez urozmaicenia, wydawała się nudna. Zboża, pola buraków, ziemniaków i znowu pola ziemniaków, buraków, zbóż - owies, jęczmień, żyto i pszenica, pszenica - dokąd sięgałam wzrokiem, wszędzie w spiekocie słońca ta sama pszenica [...]. Niemal ze strachu krzyknęłam: Tutaj mam zostać?42.

\footnotetext{
40 Zapiski autobiograficzne C. Viebig powstają w różnych momentach życia i są publikowane w różnym czasie $(1914,1925,1926,1927,1929,1930,1931)$ w rozproszonej formie m.in. w: „Berliner Tageblatt”, Kürschners Bücherschatz (Red. H. Hilger), „St. Galler Tagblatt“, „Räder“, „Kölnische Illustrierte Zeitung“, „Wiesbadener Tageblatt“, „Uhu - Das Ullstein Magazin“, „Die Literatur“, „Deutsche Presse“, „Monatszeitschrift für Freunde des Buches“, „Eifelkalender", „8 Uhr-Blatt", “Der Gesellige“. Antologia z tekstami autobiograficznymi C. Viebig (Clara Viebig. Mein Leben. Autobiographische Skizzen. Red. Ch. Aretz, Hontheim 2002) ukazuje się w 50 rocznicę śmierci pisarki i zawiera wcześniej publikowane zapiski. Zatem perspektywa autorki zależy od momentu wspominania, wzbogaconego wiedzą o rozwoju kolejnych wypadków i zdarzeń.

41 „Gott sei Dank, dass meine Mutter es nicht mehr erlebt hat, dass jene Stadt, für deren Deutschtum mein sonst so friedliebender Vater den Gewehrlauf an die Backe legte und Posten auf der Treppe stand, polnisch wurde! Dass die Stätte, mit der sie erste Liebe verknüpfte, an der ihr Vater gut deutsch gepredigt hatte, dass jene unendlichen Weizenbreiten - volle Kornkammern Preußens - den Polen anheimfielen. Und Gott sei Dank, dass sie schlafen ging vor dem größten aller Kriege“. Ch. Aretz, op. cit., s. 79.

42 „Mir, der im Westen, im schönsten Winkel der Rheinprovinz geborenen, an der sanften Mosel mit den Rebenbergen über denen eine heitere Sonne von tiefblauen Himmel lächelt, zu Hause, kam diese unabsehbare Weite, ohne Berge, ohne Abwechslung, öde vor. Kornbreiten, Rübenäcker, Kartoffelfelder, und wieder Kartoffelfelder, Rübenäcker, Kornbreiten - Hafer, Gerste, Roggen und Weizen, Weizen - wohin ich sah, immer das gleiche Wogen im Sonnenbrand. [...]. Fast angstvoll rief ich aus: Hier soll ich belieben?" Ch. Aretz, op. cit., s. 124.
} 
Mimo to poznańska monotonia jest w oczach pisarki idyllicznie piękna (około 1920 roku):

A jednak, jaki piękny jest ten płaski krajobraz! Majątki ziemskie leżą w morzu pól niczym wyspy, niczym zamknięte królestwa, każdy właściciel jak król ${ }^{43}$.

Taki sam jest nastrój wielu innych opisowych fragmentów:

Tam narodziła się moja wielka miłość do wiejskiego życia, do ziemi, do nieskończonych przestrzeni, gdzie rośnie nasz chleb. Horyzonty bez granic, szpalery drzew, które z oddali stają się niebieskie, spokojne stawy otoczone krzewami, gdzie na ciemnej wodzie pływa zadumany kwiat lilii wodnej. Kraj moich ojców, utracony, ale niezapomniany kraj!44

Z kolei A. E. Johann przemyca kwestię zmiany przynależności państwowej Kresów na dwa sposoby: zarówno pośrednio, powołując się na uczucia ojca, urzędnika pruskiego, który głęboko przeżył utratę Marchii Wschodniej [Ostmark], jak i bezpośrednio. $Z$ osobistego punktu widzenia porównuje to wydarzenie do upadku Imperium Brytyjskiego i z perspektywy kilkudziesięciu lat (Dies wilde Jahrhundert ukazuje się w 1989) konkluduje, że żadne potęgi polityczne nie są trwałe i prędzej czy później każda upadnie. Racjonalny charakter jego autobiograficznej wypowiedzi z lat 80-tych XX wieku, szczególnie na temat dokonujących się około 1918/20 roku ważnych przeobrażeń dziejowych, wystarczająco dobitnie wskazuje na wpływ dystansu czasowego na narrację o doświadczeniach sprzed wielu lat. Emocje, napięcia, które towarzyszą każdemu człowiekowi na ścieżkach życia, A. E. Johann w swojej relacji niemal pomija. To, co proponuje odbiorcy, to przekaz turbulentnych wydarzeń, opowiedzianych przez narratora, który przyjmuje postawę świadka45 i w momencie autobiograficznej relacji zna zakończenie tej historii ${ }^{46}$, przez co decyduje się na trzeźwą, wolną od emocji postawę i syntetyzując podkreśla tylko to, co w chwili wspominania wydaje się być najistotniejsze z faktograficznego punktu widzenia. Wiadomo bowiem, że różne doświadczenia nie zajmują $\mathrm{w}$ pamięci tak samo ważnego miejsca. Pamięć selekcjonuje je na te

43 „Und doch, wie schön ist auch dieses flache Land! Inseln gleich liegen die Gutshöfe im Meer der Felder, abgeschlossene Reiche für sich, jeder Gutsherr ein König“. Ch. Aretz, op. cit., s. 135.

44 „Es ist dort, dass mir meine große Liebe zum Landleben kam, zur Erde, zu den unendlichen Räumen, wo unser Brot wächst. Horizonte ohne Grenzen, Linien von Bäumen, die in der Ferne blau werden, ruhige Teiche von Büschen umgeben, wo auf dem schwarzen Wasser, nachdenklich die weiße Blüte der Seerose schwimmt. Land meiner Väter, verlorenes Land, aber niemals vergessen!“. Ch. Aretz, op. cit., s. 91.

45 M. Czermińska, Autobiograficzny trójkąt. Kraków 2000, s. 19-24.

${ }^{46}$ G. Gusdorf, Voraussetzungen und Grenzen der Autobiographie, w: Die Autobiographie. Zu Form und Geschichte einer literarischen Gattung. Red. G. Niggl, Darmstadt 1998, s. 137. 
mniej albo bardziej wartościowe i dopiero później jest im przypisywane konkretne znaczenie ${ }^{47}$.

Jeśli jednak ten jednostkowy przykład w wystarczającym stopniu nie przekonuje, że zmieniający perspektywę oglądu problemu upływ czasu może skutecznie wyciszać emocje, to zdystansowane i refleksyjne w swej wymowie stanowisko A. E. Johanna może też wynikać z faktu, że zarówno dla niego, jak i innych autobiografów, ideologiczna perswazja była na tyle męcząca i w serwowanym przez władzę wymiarze nie do zaakceptowania, iż odczuwali jej przesyt. A. E. Johann wie z doświadczenia, że dogmaty nie przetrwają próby czasu ${ }^{48}$. Dla niego potrzeba "cesarza i rzeszy" wygasła zupełnie ${ }^{49}$, a polityka po doświadczeniach I wojny światowej już go nie obchodzi, bo świat, w którym się wychował (Cesarskie Niemcy), runął. Choć bardzo dużo wie o dokonujących się w XX wieku przemianach politycznych w Niemczech, Europie i w świecie, ostatecznie decyduje się na rolę obserwatora i komentatora, a nie politycznego aktywisty, ponieważ jak pisze:

Polityka jest zawsze niewdzięczna. W miarę możliwości ograniczam się do spraw prywatnych i czysto ludzkich. Tu można przynajmniej jeszcze znaleźć odrobinę rozsądku i przyzwoitości50.

Również pastor Kurt Ihlenfeld (1901-1972) zwraca uwagę na polityczne determinanty oraz specyfikę terenów pogranicznych i stwierdza, że granice są czymś dziwnym i zagmatwanym. Trzeba mieszkać w okolicy nadgranicznej, by zrozumieć fatalizm zachodzących tam procesów ${ }^{51}$. K. Ihlenfeld porównuje pogranicze z kimś, kto w ciągu trzydziestu lat trzy, cztery razy zmienia nazwisko. Pisze, że takiego człowieka zamknięto by albo $\mathrm{w}$ domu wariatów, albo $\mathrm{w}$ więzieniu, po czym konkluduje, że nie ma większej przemocy niż przemoc zwycięskich narodów 52 .

Ernst Toller (1893-1939) łączy w swojej autobiografii wątek osobisty z kulturowo-historycznym obrazem regionu i odnosi się do znanych politycznych posunięć władz.

Dopiero po drugim rozbiorze Polski Kresy Wschodnie przypadły Prusom. Mimo to Niemcy uważali się za rdzennych mieszkańców i prawdziwych panów tego kraju, a Polaków ledwie tolerowali. Niemieccy kolonizatorzy osiedlali się we wsiach, które

${ }^{47}$ G. Baumgartner, op. cit.

48 A. E. Johann, op. cit. s. 349.

49 Ibidem, s. 196.

50 „Politik ist immer unerfreulich. Ich beschränke mich nach Möglichkeit aufs Private und Menschliche. Da läßt sich wenigstens gelegentlich Vernunft und Anstand entdecken“. A. E. Johann, op. cit., s. 213.

51 K. Ihlenfeld, Das dunkle Licht. Blätter einer Kindheit. Hamburg 1956, s. 24.

52 Ibidem, s. 25. 
niczym wysunięte naprzód warownie wbijały się klinem między wrogie polskie gospodarstwa i dwory. Niemcy i Polacy walczyli uparcie o każdy centymetr ziemi. Niemiec, który sprzedał Polakowi pole, był uważany za zdrajcę ${ }^{53}$.

Także u A. Sturm widać wyraźnie dwa światy: z jednej strony oficjalna ideologia, ale $\mathrm{z}$ drugiej jest miejsce na prywatną opinię.

Bydgoszcz, dokąd przeniesiono ojca, leżała dla mieszkańca środkowych Niemiec nieskończenie daleko. Moja mama chyba nigdy wcześniej nie słyszała nazwy takiego miasta. W ogóle Prowincja Poznańska była dla większości Niemców nieznanym krajem. W szkole uczyliśmy się, co prawda, że Fryderyk Wielki poprzez nabycie Prus Zachodnich i północnej części Poznańskiego wcielił do Prus cenną prowincję, jednak prywatnie nikt nie chciał mieć $\mathrm{z}$ tym wiele wspólnego, tak naprawdę nie było to terytorium niemieckie ${ }^{54}$.

Kiedy jednak wyjaśnia powody, dla których jej rodzice osiedlili się tu ${ }^{55}$, indywidualna, oddolna perspektywa autorki ulega wyraźnemu zbliżeniu $\mathrm{z}$ oficjalną polityką. Fakt, że jej ojca wysłano właśnie tam, miał swój szczególny powód.

$\mathrm{W}$ owym czasie, tak samo jak dzisiaj, istniało zapotrzebowanie na pełnych energii pionierów, krzewiących niemczyznę na terenach na pół polskich i mój ojciec był właśnie takim pełnym energii pionierem, który już samym wyglądem, bystrym umysłem oraz szczerym patriotyzmem działał w znacznym stopniu germanizująco ${ }^{56}$.

Wobec tego ważnego zadania, jakie z politycznych i ideologicznych powodów spoczywało na nauczycielach w Poznańskiem, A. Sturm jest rozczarowana in-

53 „Erst bei der zweiten Teilung Polens fiel die Ostmark an Preußen. Aber die Deutschen betrachteten sich als die Ureinwohner und die wahren Herren des Landes und die Polen als geduldet. Deutsche Kolonisten siedelten ringsum in den flachen Dörfern, die wie vorgeschobene Festungen sich zwischen die feindlichen polnischen Bauernhöfe und Güter keilten. Die Deutschen und Polen kämpften zäh um jeden Fußbreit Landes. Ein Deutscher, der einem Polen Land verkaufte, war als Verräter geächtet". E. Toller, op. cit., s. 2.

54 „Bromberg, wohin mein Vater versetzt war, lag einem Mitteldeutschen deshalb unendlich fern; meine Mutter hatte früher wohl kaum den Namen dieser Stadt nennen hören, wie überhaupt die Provinz Posen den meisten Deutschen ein unbekanntes Land war. Man hatte in der Schule gelernt, daß Friedrich der Große durch die Erwerbung Westpreußens und des nördlichen Teils von Posen seinem Preußen eine wertvolle Provinz einverleibt hatte; aber man mochte persönlich nicht viel damit zu tun haben, war es doch nicht echt deutscher Boden“. A. Sturm, op. cit., s. 4.

${ }_{55}$ Ojciec A. Sturm to J. H. Deinhardt (1805-1867), dyrektor bydgoskiego gimnazjum w latach 1844-1867. Autorka wspomina o politycznym wymiarze jego pracy na rzecz Marchii Wschodniej lat 60. XIX wieku.

56 „Man brauchte auch in jener Zeit, gerade wie heute, kraftvolle Pioniere für das Deutschtum in jener halb polnischen Gegend, und mein Vater war ein solch kraftvoller Pionier, der schon äußerlich sich Respekt verschaffen konnte und durch seinen lebhaften Geist und warmen Patriotismus dort in hohem Grade germanisierend gewirkt hat". A. Sturm, op. cit., s. 4. 
strumentalnym podejściem władz do spraw i problemów „pionierów niemczyzny" na Wschodzie. Czytelnik dowiaduje się z jej autobiograficznych rozważań, iż z uwagi na długoletnią pracę i zasługi jej ojca na rzecz rozwoju bydgoskiego gimnazjum, a tym samym oświaty w Prowincji Poznańskiej, życzyłaby sobie bardziej indywidualnego traktowania siebie i rodziny. Jednak uruchomiona przez urzędników w Berlinie automatyczna procedura powoduje, że rodzina Sturmów musi w Bydgoszczy na własny koszt wyremontować służbowe mieszkanie, które opuszcza. Forma urzędowej korespondencji, w której zostali o tym poinformowani, wywołuje stanowczy sprzeciw adresatki.

Wynika z tego, że zarówno A. Sturm, jak i zdecydowana większość autobiografów (wyjąwszy Julie Burow, Albert Steuer), wyjeżdża stąd. Powodem są najczęściej względy zawodowe lub podjęcie dalszej nauki. Dlatego zanim dokonamy podsumowania, należy jeszcze rozważyć czy, lub na ile, działania polityków i ideologów, zmierzające do przedefiniowania historycznego obrazu Wielkiego Księstwa Poznańskiego, przyniosły wymierne efekty w postaci lepszej identyfikacji przybyszów z zamieszkiwaną przestrzenią geopolityczną. Zmierzyć się tego oczywiście nie da, można jedynie dyskutować o pewnych tendencjach i różnych postawach wobec tej kwestii, wśród których tymczasowość pobytu należy uważać za decydujący czynnik, generujący raczej dystans do lokalnych problemów i kwestii identyfikacji z regionem. Dodatkowo pobyt na tej "pruskiej Syberii” często miał jedynie wymiar karierotwórczy. Dlatego też teza M. Broszata o niewielkiej użyteczności kadry urzędniczej wobec prób oparcia również na niej trudu panowania prusko-niemieckiego w Wielkim Księstwie Poznańskim, dość łatwo znajduje swoje uzasadnienie. Krótkowzroczność działań rządzących widać przecież nie tylko w świetle autobiografii, ale i w literaturze fachowej. Na podstawie analizy statystycznej grup zawodowych w regionie za rok 1907, M. Broszat cytując F. Swarta podkreśla, że dominującą grupę „niemieckich konsumentów stanowią przedstawiciele wojska, rosnąca armia urzędników oraz robotnicy i pracownicy zarządu poczty i kolei. Ale nie jest ona zakorzeniona na trwałe: zmiana polityki $\mathrm{w}$ stosunku do Polaków może ją zniszczyć z dnia na dzień, a tym samym usunąć podstawy, na których coraz większa część (niemieckich) kupców i rzemieślników budowała tu swoją egzystencję" 57 .

Sam fakt przyjazdu wymienionych autorów do Prowincji Poznańskiej dowodzi, że polityka wkroczyła do ich życia, mimo że w ostatecznym rozrachunku niewiele z tego wynikało dla realizacji celów (osadnictwo i integracja), które postawili sobie ideolodzy. W efekcie badani niemieccy migranci definiują się tu raczej etnicznie, a nie regionalnie. Rodziny autobiografów, jako przybysze, którzy osiedlili się w polskim otoczeniu, potwierdzają tę tezę i w pierwszym rzędzie chcą pielęgnować przynależność narodową, poprzez podobieństwo i odróżnianie się od

${ }^{57}$ M. Broszat, op. cit., s. 197. 
innych grup. W takiej atmosferze wychowują dzieci i w miarę możliwości, przez tworzenie $\mathrm{w}$ nowym środowisku transnacjonalnej przestrzeni ${ }^{58}$, izolują się od innych środowisk, dzięki czemu mentalnie nadal żyją wśród swoich, bo etniczność jest ucieczką z tej polifonicznej przestrzeni59. Z Polakami i Żydami ${ }^{60}$ stykają się jedynie w przestrzeni fizycznej. Stosunkowo rzadkie odnoszenie się do faktu mieszkających w prowincji Polaków świadczy przecież o tym, że wykorzenieni Niemcy, przybierając postawę etnocentryczną i wykluczając wszystko, co obce (czytaj: polskie), starają się pielęgnować i umacniać własną tożsamość narodową ${ }^{61}$. Izolowanie się od dominującej etnicznie (nie politycznie) grupy mieszkańców należy zatem traktować jako potwierdzenie tworzenia się tu transnacjonalnej przestrzeni, co mogą sugerować obserwacje O. Roquette, iż „polscy mieszkańcy żyli na własną rękę, odseparowani od Niemców" 62 oraz że w poczuciu niemieckości tak naprawdę utrzymywała ich „różnica względem polskiej natury” 63 .

Ostatecznie w prywatnych relacjach nie obserwuje się zwykle typowego dla ówczesnej władzy powielania stereotypów i wyolbrzymiania różnic. W tej kwestii autorzy zachowują zdrowy dystans względem poczynań władzy. Nieco dyskusji mógłby wywołać jednak O. Roquette, który negatywnie wypowiada się o Polakach, przeciwstawiając im wyższą kulturę niemieckich przybyszów:

Polacy, którzy z reguły przenosili się do miasta, majątki, których w części już nie posiadali albo poprzez złe gospodarowanie doprowadzili do tak żałosnego stanu, że ani oni, ani nikt inny nie chciał być ich właścicielem, ta polska arystokracja skupiła się wokół arcybiskupiego dworu i żyła przeszłością i w długach. [...] Z kolei przybyli ze wszystkich stron niemieccy kolonizatorzy kupili niektóre podupadłe majątki [...] i doprowadzili je dzięki lepszemu zarządzaniu do lepszego stanu, tak że dały plon. Dawni właściciele podróżowali z gotówką z ich sprzedaży do Paryża, gdzie wiedli wesołe ży-

${ }_{58}$ M. Schroer, Räume, Orte, Grenzen. Auf dem Weg zu einer Soziologie des Raums. Frankfurt/M. 2006, s. 210.

${ }^{59}$ S. Kapralski, op. cit., s. 37.

${ }^{60}$ Żydowscy autorzy (L. Kalisch i E. Toller) wyraźnie wskazują na izolację swojej grupy etnicznej i religijnej. Choć z ich strony jest gotowość bliższych kontaktów, głównie z Niemcami, jednak w tamtym momencie jest to mentalnie nie do pomyślenia.

61 „Zwłaszcza pierwsze pokolenia migrantów za szczególnie ważne uważają przekazywanie dziedzictwa kulturowego, pomagającego im utrzymać więź psychiczną z dawną ojczyzną. Jednocześnie od postawy rodziców zależy w dużej mierze ustosunkowanie potomstwa do kultury miejscowej ludności". A. Szczepaniak-Kroll, Tożsamość poznańskich rodzin pochodzenia niemieckiego: losy Bajerleinów i Dittrichów (XVIII-XX w.) Poznań 2010, s. 29-30.

Możliwie skutecznym elementem scalającym mieszkających tu autobiografów może być w związku z powyższym jedynie poczucie wspólnych losów jako pruskiej/niemieckiej kadry urzędniczej i pedagogicznej, wątpliwym pozostaje jednak, czy przekłada się ono na integrację regionalną czy wyłącznie socjalną w ramach tej samej grupy zawodowej i etnicznej.

62 O. Roquette, op. cit., s. 42.

${ }^{63}$ Ibidems. 48. 
cie. Może została im reszta na powrót, z reguły wracali bez niczego, żeby się osiedlić w mniejszych miastach prowincji - nie mając z czego żyć. Tak było w Gnieźnie ${ }^{64}$.

Obok kwestii etnicznych, dodatkowym i możliwie skutecznym elementem scalającym mieszkających tu Niemców, jest również poczucie wspólnych losów, jako pruskiej/niemieckiej kadry urzędniczej i pedagogicznej. Wątpliwe pozostaje jednak, czy przekłada się ono na integrację regionalną czy wyłącznie socjalną, w ramach tej samej grupy zawodowej i narodowej.

Uwzględnione w niniejszej analizie indywidualne doświadczenia są do pewnego stopnia homogeniczne, jednak $\mathrm{w}$ określonych obszarach nie wykluczają wielogłosu. Mógł powstać tą drogą ogląd problemu, który zbliża względem siebie naukowe wyjaśnianie istniejących związków i zależności z oddolnym, subiektywnym ich odbiorem ${ }^{65}$. Badany kontekst indywidualny otwiera, bowiem biograficzny dostęp do przeszłości, a nieoficjalna pamięć biograficzna uzupełnia oficjalną pamięć zbiorową.

64 „Die polnische Gesellschaft, welche meist von ihren Gütern in die Stadt gezogen war, Gütern, die sie zum Theil nicht mehr besaßen, oder sie durch schlechte Wirtschaft in so elenden Zustand gebracht hatten, daß weder sie noch ein Anderer sie vorerst besitzen wollte, diese polnische Aristokratie hatte sich um den erzbischöflichen Hof gesammelt, und lebte von der Tradition und von ihren Schulden. [...] Dagegen hatten deutsche Kolonisten aus allen Gegenden manche von den herunter gekommenen Gütern [...] gekauft, und sie durch bessere Wirtschaft wieder in besseren Stand und Ertrag gebracht. Die früheren Besitzer waren mit der Verkaufssumme nach Paris gereist, wo sie nun ein lustiges Leben begannen. Vielleicht blieb ihnen ein kleiner Rest für die Heimkehr, meist aber kehrten sie ohne denselben zurück, um sich nun in den kleineren Städten der Provinz niederzulassen und man wußte nicht wovon zu leben. So in Gnesen“. O. Roquette, op. cit., s. 42-43.

${ }^{65}$ A. Assmann, op. cit., s. 49. 